\title{
СРАВНИТЕЛЬНО-ПРАВОВОЙ АНАЛИЗ БРАЧНОГО ДОГОВОРА В РОССИЙСКОЙ ФЕДЕРАЦИИ И КИТАЙСКОЙ НАРОДНОЙ РЕСПУБЛИКИ
}

\section{COMPARATIVE LEGAL ANALYSIS OF THE MARRIAGE CONTRACT IN THE RUSSIAN FEDERATION AND THE PEOPLE'S REPUBLIC OF CHINA \\ I. Gribanovskaja S. Chekulaev}

Summary. The paper examines the issue of similarities and differences between the legislative institutions of the marriage contract of the Russian Federation and the PRC. As a result of applying the historical method, as well as the method of generalization, the empirical method of comparison, it was possible to detect not only differences, but also common features between the marriage contracts of the national legal systems under consideration.

Keywords: family law, marriage contract in Russia, marriage contract in China, property relations, divorce, marriage age.

\author{
Грибановская Ирина Алексеевна \\ Дальневосточный федеральный университет, \\ 2. Владивосток \\ ira0-00.00@mail.ru \\ Чекулаев Сергей Сергеевич \\ Ассистент, Дальневосточный федеральный \\ университет, г. Владивосток \\ chekylaev@mail.ru
}

Аннотация. В работе исследуется вопрос сходства и различия законодательных институтов брачного договора Российской Федерации и КНР. В результате применения исторического метода, а также метода обобщения, эмпирического метода сравнения удалось обнаружить не только различия, но и общие черты между брачными договорами рассматриваемых национальных законодательных систем.

Ключевые слова: семейное право, брачный договор в России, брачный договор в КНР, имущественные отношения, расторжение брака, брачный возpact.

В Китае государство традиционно уделяет особое внимание функционированию и укреплению института семьи, рассматривая его как основу стабильности и процветания.

Закон КНР о браке стал первым законодательным актом, принятым после образования Китайской Народной Республики, это базовый закон, регулирующий брак и семейные отношения, затрагивающий права и интересы каждого гражданина. Он был обнародован 1 мая 1950 года. Закон установил равенство мужчины и женщины в браке, свободу (от воли родителей) в заключении брака, объявил вне закона все насильственно заключенные браки, уравнял в правах внебрачных детей и детей, рожденных в браке, закрепил обязанность родителей воспитывать и содержать своих детей.

Однако в условиях набиравшей темпы модернизации китайского общества в 1980 году третьей сессией Всекитайского собрания народных представителей 5-го созыва 10 сентября 1980 г. был принят новый, второй «Закон о браке» (он вступил в силу с 1 января 1981 года), закрепивший основные принципы матримониальной системы и отношений между членами семьи: единобра- 
чие, равенство мужчины и женщины, свободное вступление в брак.

В январе 2001 года Президиум ПК ВСНП после многочисленных бурных дебатов принял решение о вынесение поправок на широкое всенародное обсуждение. Ли Пэн в своем выступлении в парламенте подчеркнул важность обсуждения поправок в Закон КНР о браке, сказав, что стабильность брака и семьи -ключевой фактор в обеспечении социальной стабильности и социального прогресса. Проект закона был опубликован 15 января 2001 года в средствах массовой информации KHP.

28 апреля 2001 года 28 сессия ПК ВСНП 9 созыва абсолютным большинством (127 голосов - за, 1 - против, 9 - воздержавшихся) утвердила новую редакцию Закона КНР о браке, которая вступила в силу в тот же день.

Целью принятия закона служило установление основных принципов брачных и семейных отношений, что четко прописано в (ст. 1 Законе КНР «О браке»)².

После истории развитии, речь пойдет о всех условиях брачного договора двух стран.

Что же представляет собой брачный договор России и KHP?

По действующему законодательству России брачным договором признается соглашение лиц, вступающих в брак или соглашение супругов, определяющее имущественные права и обязанности супругов в браке и (или) в случае его расторжения(ст. 40 СК РФ). Брачный договор может быть срочной, а также условной сделкой (п. 2 Ст. 24 (K PФ) ${ }^{3}$.

По мнению цивилиста Хэ Чжи, “брачный договор рассматривается как гражданско-правовая сделка в той мере, в какой регулируемые им отношения составляют предмет гражданского права, а когда регулируемые им отношения носят личный, неимущественный характер, он не может считаться гражданско-правовой сделкой"4. Заключение брачного контракта сегодня в Китае считается нормальным делом. Хотя заключают его пока немногие.

Имея понятие определения брачного договора, перейдем к условиям. в его:

Особенность брачного договора России заключается

- особом субъективном составе;

- форме;

- содержанию;
Кратко раскроем каждую особенность.

Субъектами брачного договора могут быть лица, вступающие в брак (т.е. брачный договор обычно заключается перед государственной регистрацией заключения брака).

Как и в Российском законодательстве в КНР субъектами брачного договора могут быть лица, вступающие в брак.

Регистрация брака осуществляется органами регистрации браков, в который будущие супруги обязаны обратиться лично. Если соблюдены все требования закона, то орган регистрирует брак и выдает свидетельство о браке. С момента регистрации брака между мужчиной и женщиной возникают супружеские отношения.

Интересно различие брачного возраста России и КНР.

В Китае самый высокий порог брачного возраста в мире: 20 лет для женщин и 22 года для мужчин. В отличие от России где заключить брак можно с 18 лет.

Считается, что к этому возрасту люди могут стать достаточно самостоятельными и в эмоциональном, и в материальном плане и сделать осознанный выбор. Должны поощряться поздние браки и позднее деторождение. В отличие от России.

В России же лицо не достигшее брачного возраста, имеет право заключить брачный договор. Для этого несовершеннолетний обязан в законном порядке получить разрешение органа опеки и попечительства на вступление в брак.

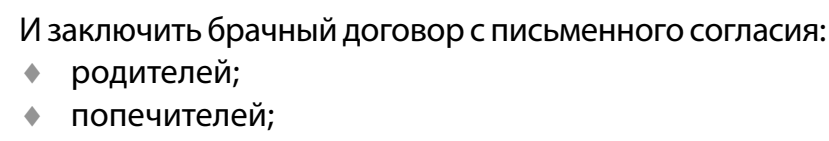

Содержание брачного договора - это условия, которыми его субъекты определяют соответствующий правовой режим имущества супругов.

Теперь перейдем к рассмотрению имущественных отношений супругов.

В России регулирование имущественных отношений супругов регламентируется ст. 42 СК РФ.

Условия которые могут быть включены в брачный договор:

- супруги вправе по своему усмотрению включать в брачный договор любые, не противоречащие закону условия; 
- в том числе и о распоряжении имуществом, являющимся личным имуществом каждого из супругов;

Однако в научной литературе ставится вопрос о необходимости включения в содержание брачного договора также неимущественных отношений. В этом случае можно согласиться с точкой зрения Л.Б. Максимовича, что содержание личных неимущественных прав и обязанностей урегулировано в законе и по общему правилу не может быть изменено соглашением сторон, а если таковое все же заключается, то оно носит неправовой характер ${ }^{5}$.

Действительно данный правовой институт не может ограничивать:

- правоспособность и дееспособность супругов;

- их право на обращение в суд за защитой своих прав;

- регулировать личные неимущественные отношения между супругами;

- права и обязанности супругов в отношении детей;

- права нетрудоспособного нуждающегося супруга на получение содержания и др.

При этом предметом брачного договора может являться как уже имеющееся, так и будущее имущество супругов.

В частности, представляется недопустимой, противоречащей действующему законодательству практика, когда брачный договор содержит другие условия, противоречащие нормам семейного законодательства. Из сказанного следует, что законодательство РФ разрешает включение в брачный договор условий, касающихся исключительно имущественных отношений супругов.

Как и в Российском законодательстве в КНР институт брака не может ограничивать:

- правоспособность и дееспособность супругов;

- их право на обращение в суд за защитой своих прав;

- регулировать личные неимущественные отношения между супругами;

- права и обязанности супругов в отношении детей;

- права нетрудоспособного нуждающегося супруга на получение содержания и др.

Суть брачного договора определяется правом супругов на самостоятельный выбор правового режима их имущества. Как и с другими условиями, так и с обязанностями Россия и КНР схожи.

В российском законодательстве одной из обязанностей супругов является обязанность по взаимной мате- риальной поддержке (п. 1 ст. 89 СК РФ). Так же супруги вправе определить свои права и обязанности по взаимному содержанию в брачном договоре.

Так и в КНР супруги несут обязанность содержать друг друга. В случае невыполнения одним из супругов обязанности по содержанию, нуждающаяся сторона имеет право потребовать от данной стороны выплаты расходов по содержанию(ст. 20 Закона).

Брачный договор по российскому праву и КНР не может содержать условия, которые ставят одного из супругов в крайне неблагоприятное положение или противоречат основным началам семейного законодательства.

Суд в каждом конкретном случае с учетом всех обстоятельств дела по своему внутреннему убеждению определяет, поставили ли условия брачного договора одного из супругов в крайне неблагоприятное положение. В судебной практике к критериям «крайне неблагоприятного положения» относятся, в частности, случаи, когда один из супругов полностью лишается права собственности на имущество, нажитое супругами в период брака ${ }^{6}$, либо в брачном договоре налицо существенная непропорциональность долей в общем имуществе 7

На данный момент в Законодательную Думу РФ внесен законопроект, которым предлагается исключить положение о запрете включения в брачный договор условий, ставящих одного из супругов в крайне неблагоприятное положение ${ }^{8}$. Авторами законопроекта обосновывается это тем, «что многие супруги опасаются признания заключенного между ними брачного договора недействительным в связи с тем, что его условия рано или поздно поставят одного из них в неблагоприятное положение» 9 .

В настоящее время существование данной нормы необходимо, как способа защиты супруга, оказавшегося в крайне невыгодном положении в результате недобросовестного поведения другого супруга в имущественных отношениях. Ведь большинство признаваемых недействительными по данному основанию брачных договоров заключаются с размытой формулировкой о раздельной собственности на все имущество супругов - «на чье имя оформлено, собственностью того и является». А по итогу оказывается, что все имущество, приобретаемое в браке, оформляется на одного из супругов, а другой остается ни с чем.

В завершение анализа сравним такое понятие, как “расторжение брака".

Как в России, так и в КНР расторжение брака возможно по обоюдному согласию супругов, а также по требованию одной из сторон, в крайнем случае через суд. 
Норма закреплена в Семейном кодексе РФ гл. 4 и Закон КНР гл. 4.

В результате исследования сравнительно-правовой анализ брачного договора в Российской Федерации и Китайской Народной Республики позволяет сделать вывод, что брачный договор, со всеми условиями схожи друг с другом.
В Китае законодательство о браке и семье характеризуется простотой и обобщенностью, как и институт брачного договора. В российском законодательстве в сфере регулирования договорных отношений между супругами нуждается в усовершенствовании ввиду существования определенных пробелов в правовом регулировании этой сферы, что порождает последующие проблемы правоприменения.

\section{ЛИТЕРАТУРА}

1. URL: https://bstudy.net/683109/pravo/prava_suprugov_zakreplenie_brachnom_dogovore.

2. Закон КНР «0 браке» от 10.09.2001 в ред. от 28.04.2001.

3. Семейный кодекс Российской Федерации от 29.12.1995 в ред. от 06.02.2020.

4. Хэ Чжи. Договорное регулирование имущественных отношений в семье. Пекин: Изд-во китайского университета политики и юриспруденции, 2016. С. 116.

5. Максимович Л. Б. Брачный договор в российском праве. М.,2003. С. 127.

6. п применении судами законодательства при рассмотрении дел о расторжении брака: Постановление Пленума Верховного Суда РФ от 05.11.1998 № 15 // Бюллетень Верховного Суда Российской Федерации. — 1999.— № 1.

7. Определение Судебной коллегии по гражданским делам Верховного Суда РФ от 20.12.2016 № 5-КГ16-17 [Электронный ресурс] — Доступ из справ. правовой системы «КонсультантПлюс», раздел «Судебная практика» (дата обращения: 02.01.2020).

8. 0 внесении изменений в отдельные законодательные акты Российской Федерации: проект Федерального закона № 835938-7 [Электронный ресурс] Доступ из справ. — правовой системы «КонсультантПлюс» (дата обращения: 02.01.2020).

9. Пояснительная записка к проекту Федерального закона «0 внесении изменений в отдельные законодательные акты Российской Федерации» [Электронный ресурс] — Доступ из справ. — правовой системы «КонсультантПлюс» (дата обращения: 02.01.2020).

(c) Грибановская Ирина Алексеевна ( ira0-00.00@mail.ru ), Чекулаев Сергей Сергеевич ( chekylaev@mail.ru ).

Журнал «Современная наука: актуальные проблемы теории и практики»

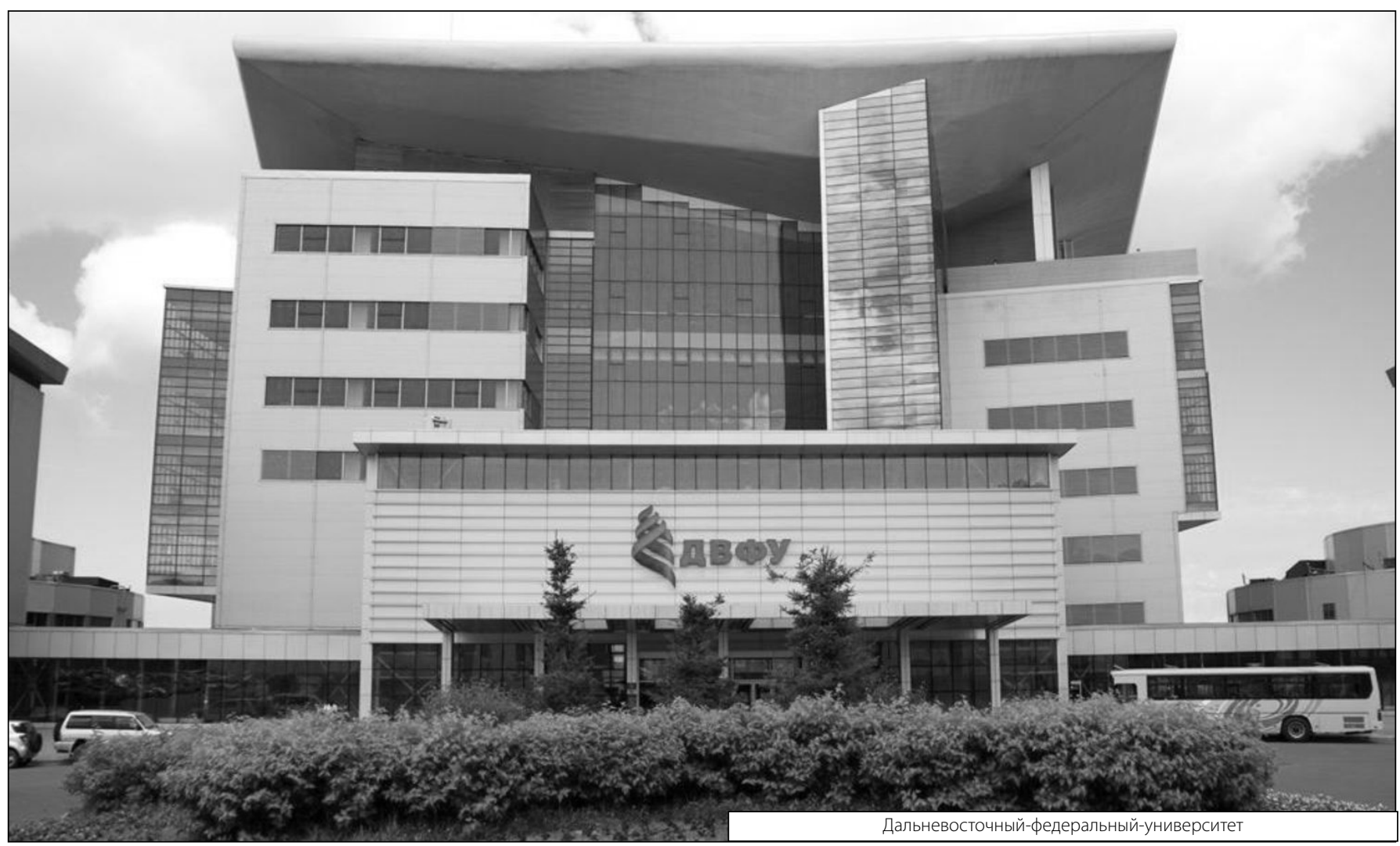

